Short Communication

\title{
OCCURRENCE OF CRYPTOSPORIDIUM SPP. AND GIARDIA DUODENALIS IN RED FOXES (VULPES VULPES) IN BOSNIA AND HERZEGOVINA
}

\author{
Adnan Hodžić ${ }^{1}$, Amer Alić$^{2}$, Jasmin Omeragić ${ }^{1}$ \\ ${ }^{1}$ Department of Parasitology and Invasive Diseases, Veterinary Faculty, \\ University of Sarajevo, Zmaja od Bosne 90, 71000 Sarajevo, Bosnia and Herzegovina \\ ${ }^{2}$ Department of Pathology, Veterinary Faculty, University of Sarajevo, \\ Zmaja od Bosne 90, 71000 Sarajevo, Bosnia and Herzegovina
}

Received 27 January 2014; Received in revised form 26 February 2014; Accepted 31 March 2014

\begin{abstract}
The aim of this study was to determine the occurrence and distribution of Cryptosporidium spp. and Giardia duodenalis among free-living red foxes (Vulpes vulpes) in Bosnia and Herzegovina. For this purpose, a total of 123 fecal samples from red foxes, shot during hunting seasons between January 2011 and March 2012 were examined using immunofluorescent microscopy. Overall, observed prevalences of Cryptosporidium spp. and Giardia duodenalis were 3.2 \% (4/123) and 7.3\% (9/123), respectively. The results show that foxes might play the role of potential reservoirs of Cryptosporidium and Giardia parasites, but further molecular analysis are necessary to elucidate the source of infection, routes of transmission and zoonotic potential of these two pathogens.
\end{abstract}

Key words: Bosnia and Herzegovina, Cryptosporidium spp., Giardia duodenalis, immunofluorescence, red fox

\section{INTRODUCTION}

Cryptosporidium spp. and Giardia duodenalis are ubiquitous intestinal protozoan parasites that are recognised as prevalent and widespread pathogens of humans and domestic animals. They are being increasingly recognised as parasites of a diverse range of wildlife species $(1,2,3,4)$. Their life cycles are completed within an individual host, with transmission by the direct fecal-oral route or through ingestion of contaminated food or water $(1,2,5)$. The red fox (Vulpes vulpes) is the most abundant wild canid species living in Bosnia and Herzegovina and is considered to be an important source of potentially zoonotic Cryptosporidium and

Corresponding author: Adnan Hodžić, MVSc

E-mail address: adnan.hodzic@vfs.unsa.ba

Present address: Department of Parasitology and Invasive Diseases,

Veterinary Faculty, University of Sarajevo,

Zmaja od Bosne 90, 71000 Sarajevo,

Bosnia and Herzegovina

Phone: +38733610908

Copyright: (C) 2014 Hodžić A. This is an open-access article published under the terms of the Creative Commons Attribution License which permits unrestricted use, distribution, and reproduction in any medium, provided the original author and source are credited.

Competing Interests: The authors have declared that no competing interests exist.

Available Online First: 25 April 2014

http://dx.doi.org/10.14432/j.macvetrev.2014.04.012
Giardia parasites, for both humans and domestic animals $(6,7,8)$. Despite their hunting, the population density and distribution of red foxes has increased throughout Europe as a consequence of intensive oral anti-rabies vaccination programs (9). In Bosnia and Herzegovina, according to the State Veterinary Office, the total number of red foxes is about 21,000. Their number has been estimated to grow since the oral vaccination program started in October 2011. The growing population of red foxes, which have become synantropic animals in some cases, increases the risk of human and domestic animal contact with (oo)cysts, via feces contaminated pastures, water and recreational areas and has important implications for the control and prevention of these pathogens in rural and periurban areas. However, very few studies $(3,6$, $7,8,10$ ) have been carried out and little information is available on the prevalence, distribution and genetic characterization of Cryptosporidium spp. and Giardia duodenalis in red foxes. The aim of this study was to determine the occurrence and distribution of Cryptosporidium spp. and Giardia duodenalis among free-living red foxes in Bosnia 
and Herzegovina, since no studies have been conducted to date in this area.

\section{MATERIALS AND METHODS}

The study area was the entire territory of Bosnia and Herzegovina which covers 51,209.2 $\mathrm{km}^{2}$ and it is located in the western part of the Balkan Peninsula $\left(43^{\circ} 52^{\prime} \mathrm{N}, 28^{\circ} 25^{\prime} \mathrm{E}\right)$. The geography is characterized by major differences which determine variations in climate, vegetation and landscape. The central and eastern parts of the country are mountainous (from 500 to over $2.000 \mathrm{~m}$ above the sea level) and are characterized by continental mountain climate and average annual precipitation ranging from 1.000 to $1.2001 / \mathrm{m}^{2}$. The northwest is moderately hilly, while the northeast is predominantly flatland, with moderate continental climate and an average annual precipitation ranging from 700 to $1.3001 / \mathrm{m}^{2}$. The southern part of the country (Herzegovina) has a mediterranean climate with very high precipitation (from 1.000 to $1.8001 / \mathrm{m}^{2}$ ) and dominant karst and plain topography. Absolute minimum temperature during the winter seasons is about $-35^{\circ} \mathrm{C}$, while in the summer periods the absolute maximum temperature can reach $45^{\circ} \mathrm{C}$. About $43 \%$ of territory is forested and most of the forest areas are in the central, eastern and western parts of the country.

Fecal samples from 123 red foxes (63 males, 43 females, 17 unknown), mostly originating from mixed and coniferous forests in six different regions (Table 1), were collected during the hunting season, between January 2011 and March 2012.

The samples were analyzed for the presence of Cryptosporidium spp. and Giardia duodenalis (oo)cysts by a sucrose flotation concentration and immunofluorescent staining method, using FITCconjugated (oo)cysts wall-specific monoclonal antibodies (MerIFluor Cryptosporidium/Giardia, Meridian Bioscience, Cincinnati, OH, USA) as previously described $(11,12)$.

\section{RESULTS}

Cryptosporidium spp. and Giardia duodenalis were detected in $4(3.2 \%)$ and $9(7.3 \%)$ samples, respectively. Co-infection with both parasites was not detected. Prevalences and geographical distribution of infected animals are shown in Table 1 and Figure 1.

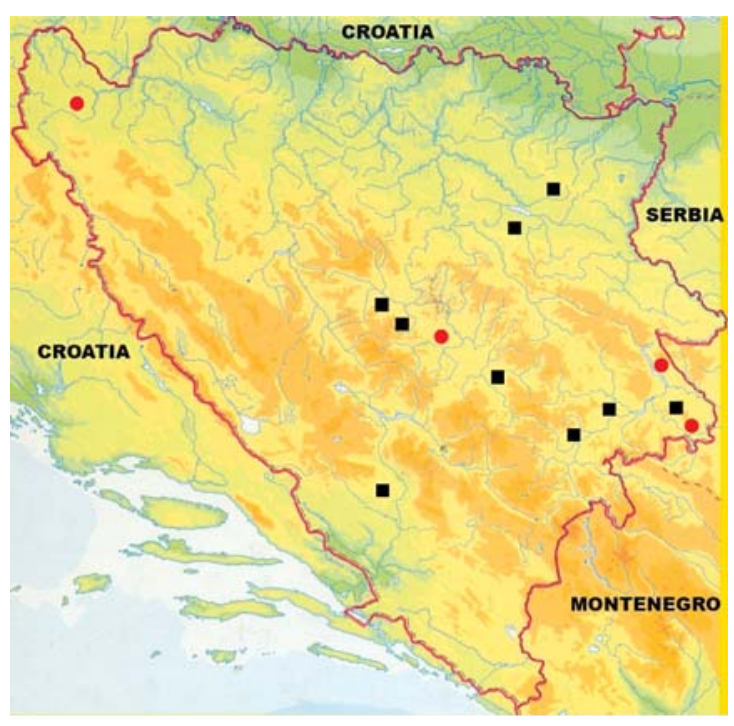

Figure 1. Geographical distribution of Cryptosporidium spp. (•) and Giardia duodenalis ( $\bullet$ ) infected foxes in Bosnia and Herzegovina

Table 1. Prevalences of Cryptosporidium spp. and Giardia duodenalis in Bosnia and Herzegovina

\begin{tabular}{|c|c|c|c|c|c|}
\hline \multirow{2}{*}{ Region } & \multirow{2}{*}{ Examined foxes } & \multicolumn{2}{|c|}{ Cryptosporidium spp. } & \multicolumn{2}{|c|}{ Giardia duodenalis } \\
\hline & & $\mathrm{n}$ & $\%$ & $\mathrm{n}$ & $\%$ \\
\hline Central Bosnia & 41 & 1 & 2.4 & 3 & 7.3 \\
\hline North Bosnia & 5 & 0 & 0.0 & 0 & 0.0 \\
\hline North East Bosnia & 26 & 0 & 0.0 & 2 & 7.7 \\
\hline East Bosnia & 19 & 2 & 10.5 & 3 & 15.7 \\
\hline North West Bosnia & 12 & 1 & 8.3 & 0 & 0.0 \\
\hline Herzegovina & 20 & 0 & 0.0 & 1 & 5.0 \\
\hline Total & 123 & 4 & 3.2 & 9 & 7.3 \\
\hline
\end{tabular}

$\mathrm{n}$ - number of infected animals 
Occurrence of Cryptosporidium spp. and Giardia duodenalis in red foxes

\section{DISCUSSION}

Based on our results, the prevalences of Cryptosporidium spp. and Giardia duodenalis in the red fox population, were found to be relatively low but widespread. All infected foxes inhabit areas ranging from 126 to $1.201 \mathrm{~m}$ above sea level. Among all the regions surveyed in this study, the highest prevalences were detected in the region of East Bosnia (10.5\% and 15.7\%). The possible explanation for this observation and the main factor favoring infection with these two water-borne pathogens, could be the existence of large floodplain areas around the Drina river (lenght: $346 \mathrm{~km}$ ) and its tributaries which flood the habitats, leaving numerous swamps after abundant rainfall. In contrast, much lower prevalences were recorded in Hercegovina $(0.0 \%$ and $5.0 \%)$, most likely due to the high permeability of karst soil and the lack of surface waters.

Lower prevalence of $1,6 \% \quad(2 / 124)$ of Cryptosporidium spp. was found in red foxes from 19 counties in Ireland (3), while the prevalence found by Zhou et al. (6) in Maryland, USA was 8.0\% (6/76). Ravaszova et al. (10) examined fecal samples of 62 red foxes from the Slovak Republic using two different diagnostic methods, Cryptosporidium sandwich ELISA and modified Kinyoun's acid-fast stain and found a very high prevalence of $38.7 \%$ (24/62) and 20.96\% (13/62), respectively. Hamnes et al. (7) detected Cryptosporidium oocyst in 6 $(2.2 \%)$ and Giardia cysts in $13(4.8 \%)$ fecal samples from the total of 269 Norwegian red foxes, while Beck et al. (8) found the same prevalence (4.5\%) of Giardia duodenalis in Croatia. The results of molecular genetic studies demonstrated that foxes can be infected with the Cryptosporidium canis fox genotype, the Cryptosporidium muskarat genotype and the Cryptosporidium canis dog genotype, which is the only known human pathogen (6). Nucleotide sequence analysis of the $g d h$, $S S U-r D N A$ and $\beta$-giardin genes of Giardia duodenalis, demonstrated a high degree of heterogeneity and the genotyping information showed the occurrence of zoonotic Assemblages A and $B$ in red foxes, suggesting a potential role of these animals as a source of infections for humans or other animals $(7,8)$.

\section{CONCLUSION}

In conclusion, the results of the present study show that foxes might be potential reservoirs of Cryptosporidium spp. and Giardia duodenalis, but further molecular analysis are necessary to elucidate the source of infection, the routes of transmission and the zoonotic potential of these two pathogens. This is the first report on the occurrence of Cryptosporidium spp. and Giardia duodenalis in the red fox population from Bosnia and Herzegovina.

\section{ACKNOWLEDGMENT}

Authors would like to thank Ajša Kos and Samir Bogunić for their techical support, as well as all hunting societies which participated in this study.

\section{REFERENCES}

1. Fayer, R. (2004). Cryptosporidium: a water-borne zoonotic parasite. Vet Parasitol. 126, 37-56. http://dx.doi.org/10.1016/j.vetpar.2004.09.004 PMid:15567578

2. Appelbee, A.J., Thompson, R.C.A., Olson, M.E. (2005). Giardia and Cryptosporidium in mammalian wildlife - current status and future needs. Trends Parasitol. 21, 370-376.

http://dx.doi.org/10.1016/j.pt.2005.06.004

PMid:15982929

3. Nagano, Y., Finn, M. B., Lowery, C. J., Murphy, T., Moriarty, J., Power, E., Toolan, D., O’Loughlin, A., Watabe, M., McCorry, K. A., Crothers, Dooley, J. S. G., Rao, J. R., Rooney, P. J., Millar, B. C., Matsuda, M., Elborn, J.S., Moore, J.E. (2007). Occurrence of Cryptosporidium parvum and bacterial pathogens in faecal material in the red fox (Vulpes vulpes) population. Vet Res Commun. 31, 559-564. http://dx.doi.org/10.1007/s11259-007-3519-1 PMid:17225081

4. Thompson, R. C. A., Colwell, D. D, Shury, T., Appelbee, A. J, Read, C., Njiru, Z., Olson, M. E. (2009). The molecular epidemiology of Cryptosporidium and Giardia infections in coyotes from Alberta, Canada, and observations on some cohabiting parasites. Vet Parasitol. 159, 167-170. http://dx.doi.org/10.1016/j.vetpar.2008.10.003 PMid:19019549 
5. Carmena, D., Cardona, G. A., Sánchez-Serrano, L. P. (2012). Current situation of Giardia infection in Spain: Implications for public health. World J Clin Infect Dis. 2, 1-12.

http://dx.doi.org/10.5495/wjcid.v2.i1.1

6. Zhou, L., Fayer, R., Trout, J. M., Ryan, U. M., Schaefer III, F. W., Xiao, L. (2004). Genotypes of Cryptosporidium species infecting fur-bearing mammals differ from those of species infecting humans. Appl Environ Microbiol. 70, 7574-7577. http://dx.doi.org/10.1128/AEM.70.12.7574-7577.2004 PMid:15574965 PMCid:PMC535153

7. Hamnes, I. S., Gjerde, B. K., Forberg, T., Robertson, L. J. (2007a). Occurrence of Giardia and Cryptosporidium in Norwegian red foxes (Vulpes vulpes). Vet Parasitol. 143, 347-353.

http://dx.doi.org/10.1016/j.vetpar.2006.08.032

PMid: 17045400

8. Beck, R., Sprong, H., Lucinger, S., Pozio, E., Cacció, S. M. (2011a). A large survey of Croatian wild mammals for Giardia duodenalis reveals a low prevalence and limited zoonotic potential. Vec Born Zoo Dis. 8, 1049-1055.

http://dx.doi.org/10.1089/vbz.2010.0113

PMid:21142957
9. Gloor, S., Bontadina, F., Hegglin, D., Deplazes, P., Breitenmoser, U. (2001). The rise of urban fox populations in Switzerland. Mamm Biol. 66, 155164.

10. Ravaszova, P., Halanova, M., Goldova, M., Valencakova, A., Malcekova, B., Hurnìková, Z., Halan, M. (2012). Occurrence of Cryptosporidium spp. in red foxes and brown bear in the Slovak Republic. Parasitol Res. 110, 469-471.

http://dx.doi.org/10.1007/s00436-011-2523-0

PMid:21744018

11. Hamnes, I. S, Gjerde, B. K., Robertson, L. J. (2007b). A longitudinal study on the occurrence of Cryptosporidium and Giardia in dogs during their first year of life. Acta Vet Scand. 49, 22.

http://dx.doi.org/10.1186/1751-0147-49-22

PMid:17848186; PMCid:PMC2040143

12. Beck, R., Sprong, H., Bata, I., Lucinger, S., Pozio, E., Cacció, S. M. (2011b). Prevalence and molecular typing of Giardia spp. in captive mammals at the ZOO of Zagreb, Croatia. Vet Parasitol. 175, 40-46. http://dx.doi.org/10.1016/j.vetpar.2010.09.026 PMid:20970259 